\title{
HISTOPATHOLOGICAL PICTURES, INNERVATION AND CLINICAL CONSIDERATIONS OF HUMAN PALATINE TONSILS.
}

\author{
By \\ K. NAGASE \\ From the Department of Otorhinolaryngology, School. of Medicine, \\ Keio University (Director: Prof. T. Nishihata)
}

Of surgically removed tonsils the histopathological pictures and the distribution of the nerves, especially of the vegetative nerves, were systematically studied.

In all cases cornification was found in the stratified squamous epithelium of the oral surface of the tonsil. The histological structure of the capsule of the tonsil showed a considerable individual difference. The course of the skeletal muscle fibres and bandles were especially different. Frequently they ran closely to the parenchyma and entered into the inlet of the septum. Therefore, histologically, the so-called capsule is a portion of the tunica propria of the oral mucous membrane and should not be regarded as an entity.

On the basis of these findings tonsilar abscess was assumed to be formed in the parenchyma or in or out of the capsule under certain conditions such as the bacterial toxicity and the resistance of the patient. Considerations were also made on the nature of peritonsilar abscess.

The sensory nerve endings were sparse in the tunica propria under the epethelium. Relatively numerous simple and complicated arborating endings were found in the capsule, especially in the transitional part to both palatine arches. Un-arboraing endings and rarely simple glomerular endings were also observed. In the tonsilar parenchyma and septum simple and complicated arborating endings were also found. However, the epithelium showed no nerve ending. The vegetative nerves were richly found and implied the importance of the position of the tonsil. They sent nervous anastomoses to the vascular walls and were widely distributed forming the so-called terminal net work of the vegetative nerves. It was especially noteworthy that neurofibrillae entered from the surroundings of the lymph follicles into the germinal centres accompanying the precapillaries which were radially distributed in the follicles.

On the basis of the above stated findings the intense pain of peritonsilar abscess was easily explained. Thus, in tonsillectomy, injection of the anesthetic to the tonsilar capsule, especially at the transitional part of both palatine arches, was indicated and the focal infection of the tonsil, e.g. myocardial disturbances due to peritonsilar abscess, was considered from the standpoint of the Reilly phenomenon. 


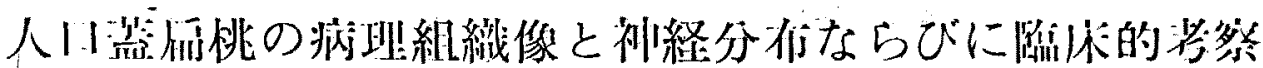

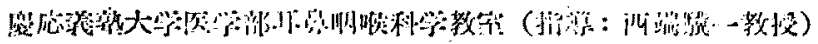

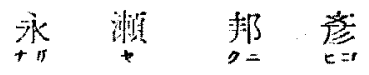

\section{目次}

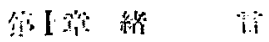

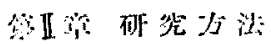

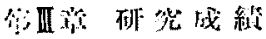

A. 瘦挑の Hämatoxylin-Eosin 染他与きび Mallory 渄仙による睍

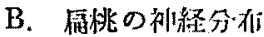

1. 知觉㖄綕の分枋

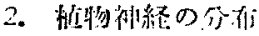

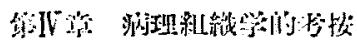

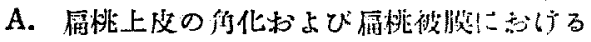

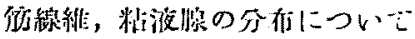

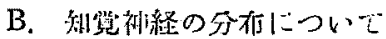

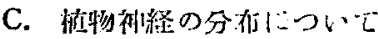

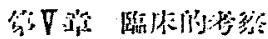

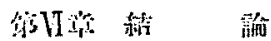

\section{第I章 緒言}

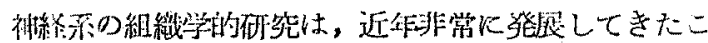

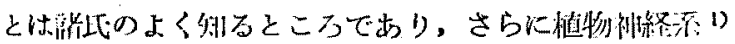

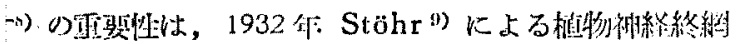
(vegetatives Terminalreticulum) の独兒以来， 生'!

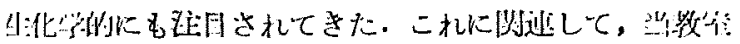

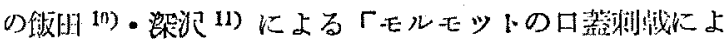

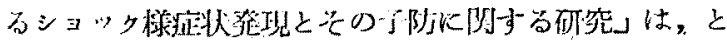

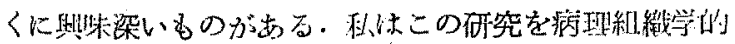

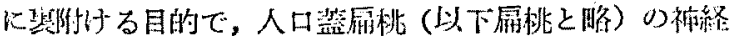

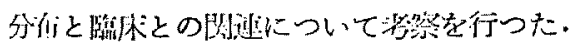

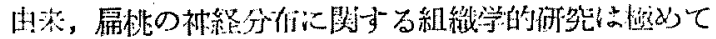

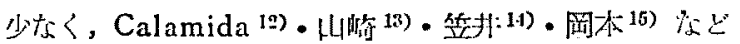

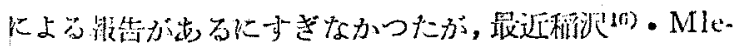

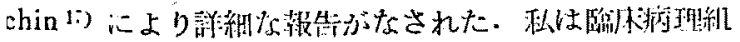

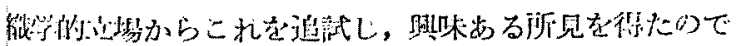
発者的分。

\section{第1I章 研究方法}

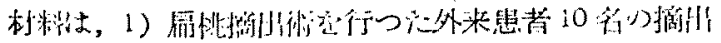

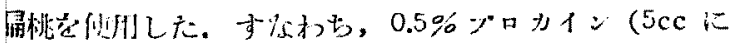

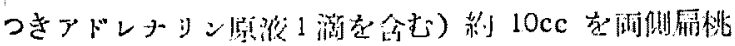

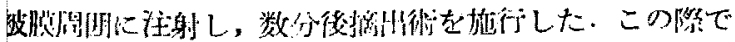

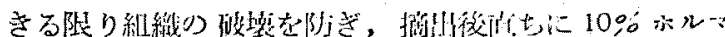

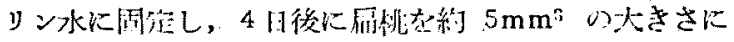

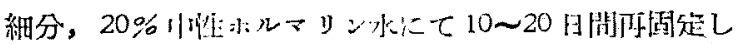

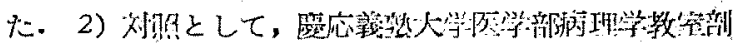

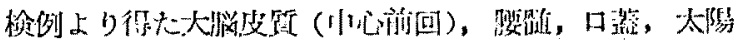

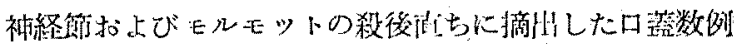

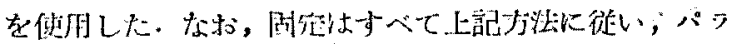

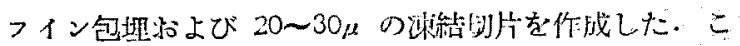

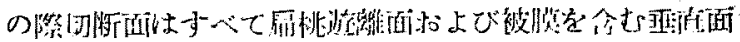
とした、染包仕 Hämatoxylin-Eosin 染何, Mallory

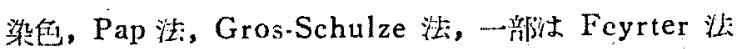

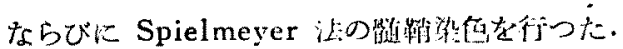

\section{第III章 研究成精}

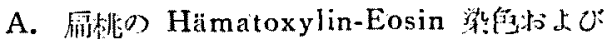

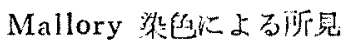

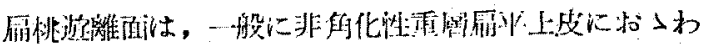

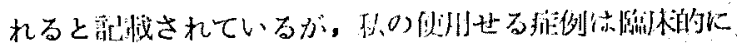

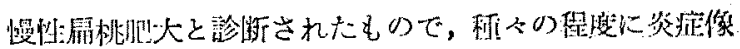

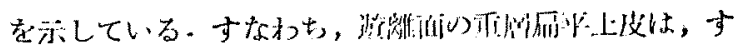

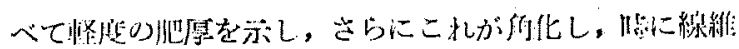

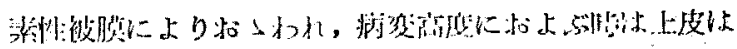

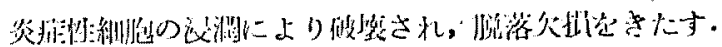

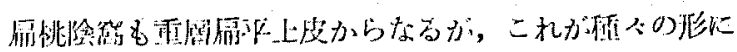

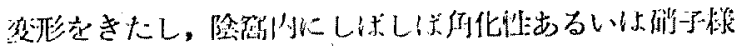

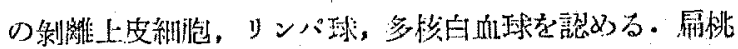

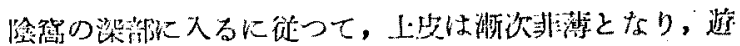

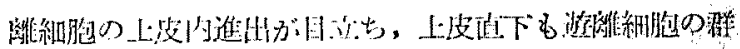

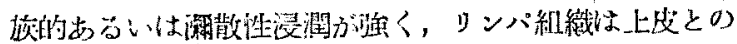

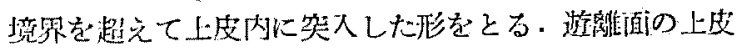

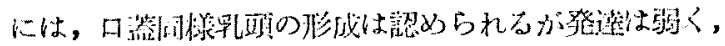

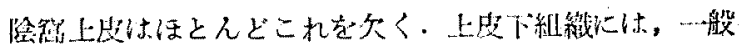

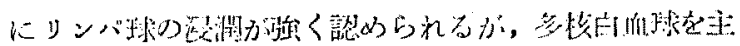

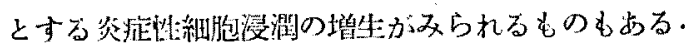

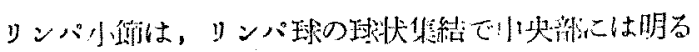

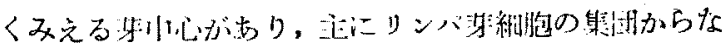

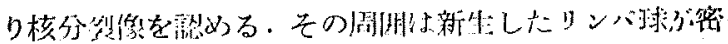

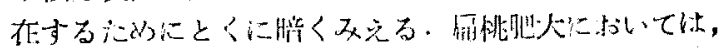

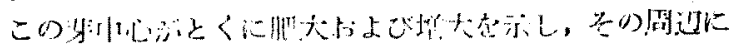


第 1 表 整蓬の磟妨られるもの

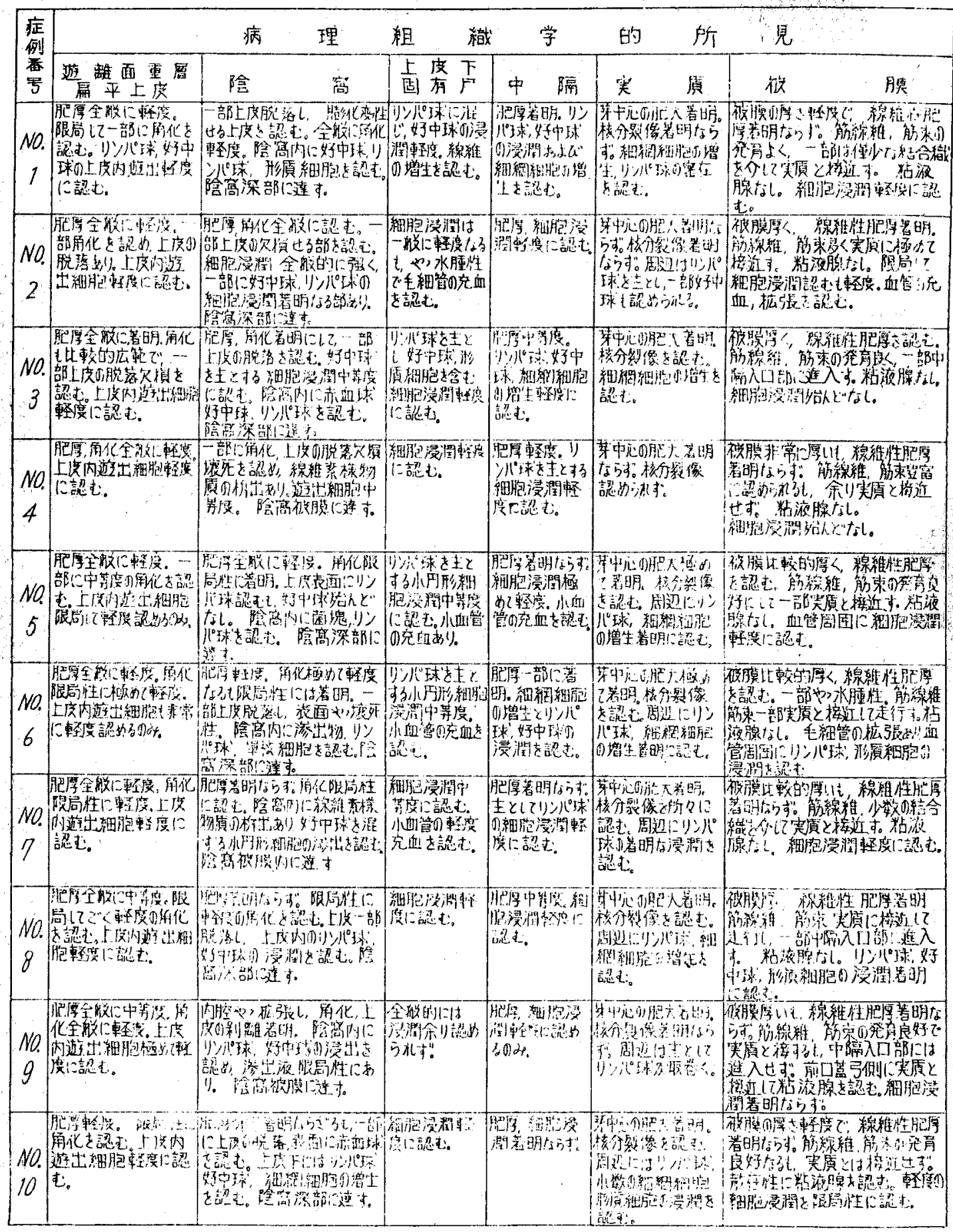

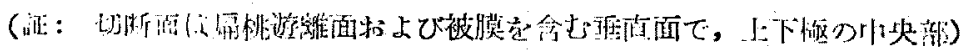




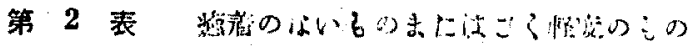

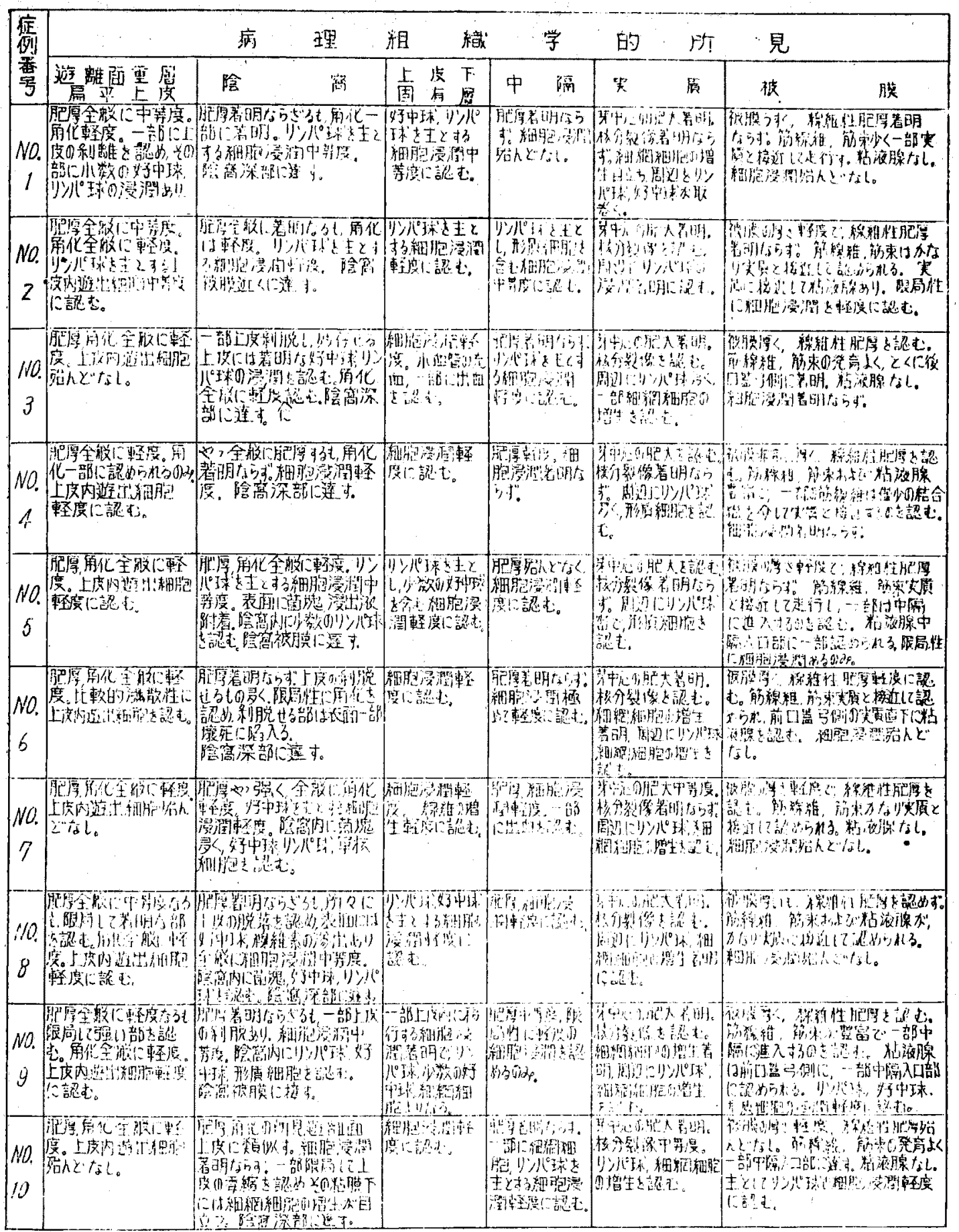

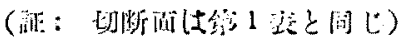


4t y -

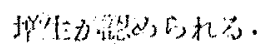

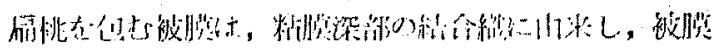

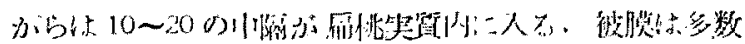

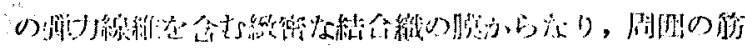

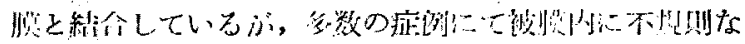

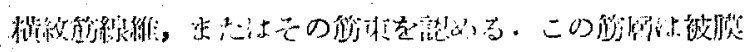

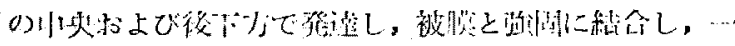

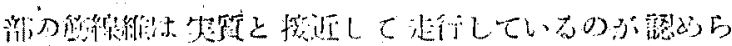

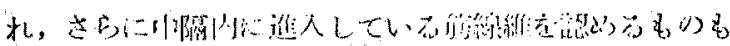

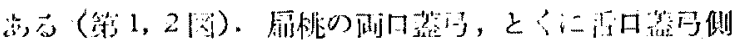

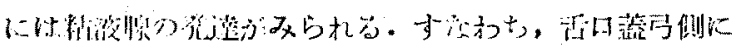

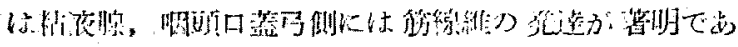

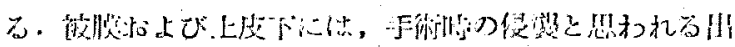

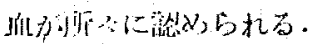

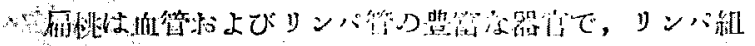

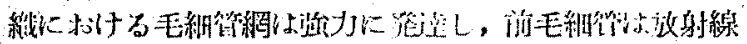

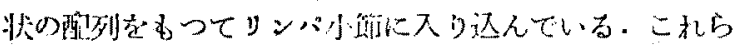

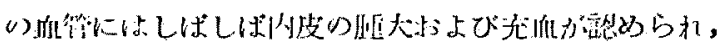

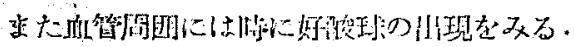

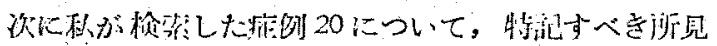

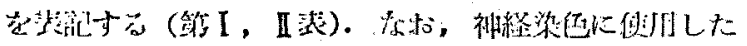

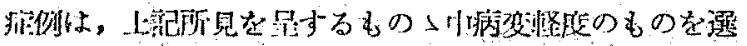
んた:

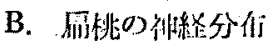

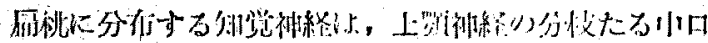

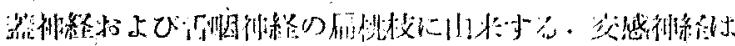

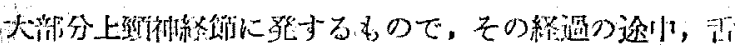

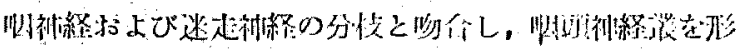

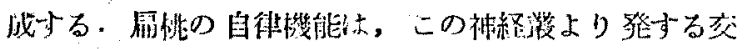

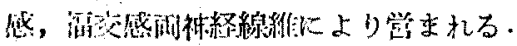

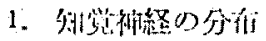

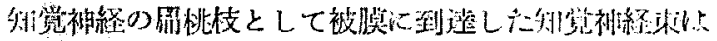

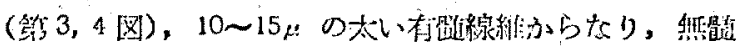

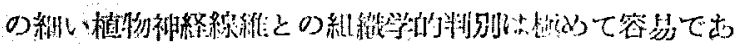

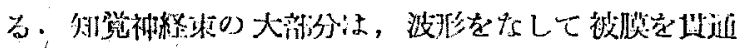

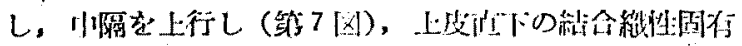

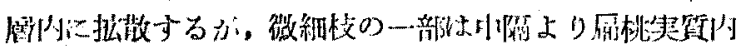

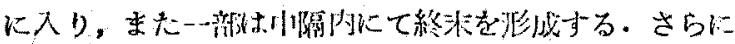

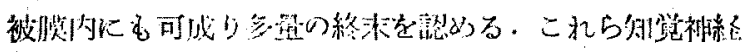

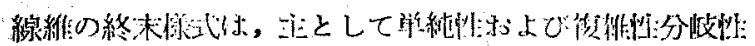

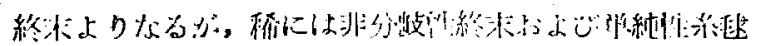

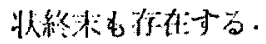

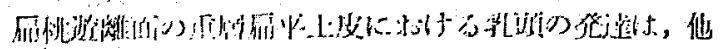

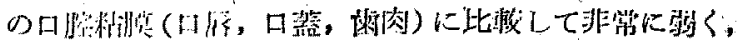

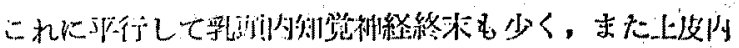

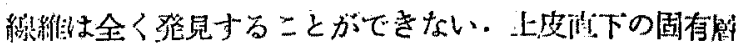

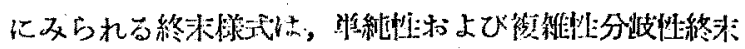

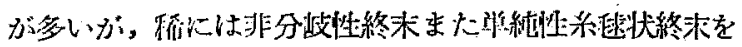

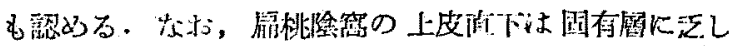
く，刘登神経終来の形成は殆えど存在しない。

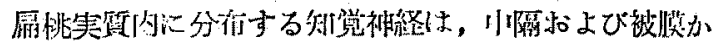
ら進入する神経原線維よりなるが，一部刃神経線維甠有

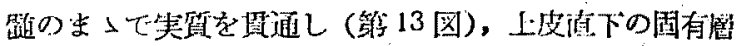

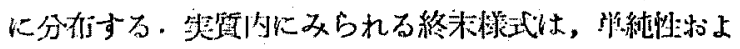

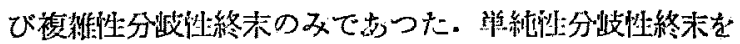

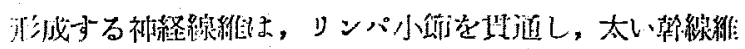

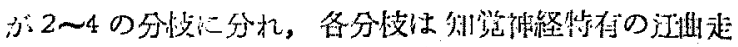
行をし，主として处锐状に終る（第10图）。複雑性分肢

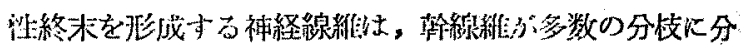

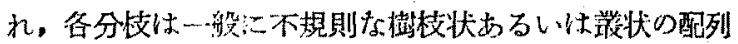

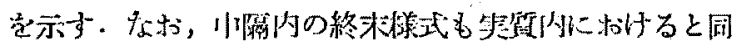
椎の所見を示す。。

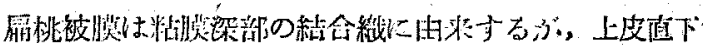

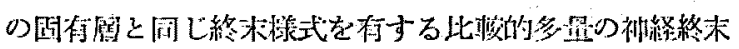

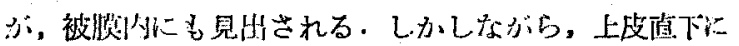

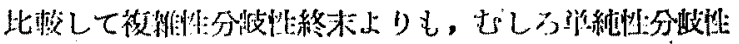

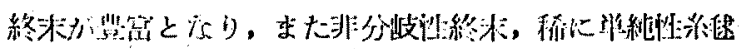

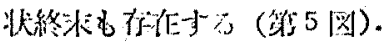

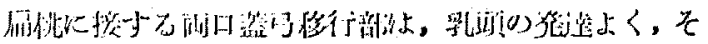

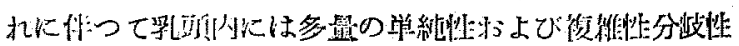

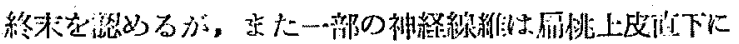

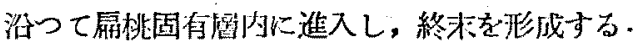

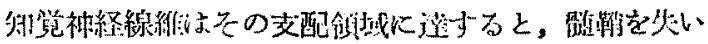

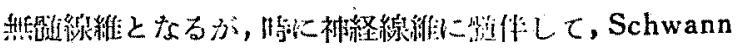

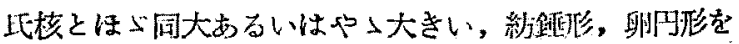

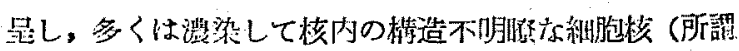

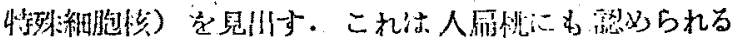

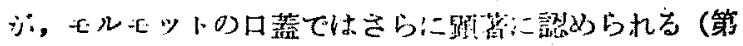
15, 16 図).

\section{2. 植物被䋂の分有i}

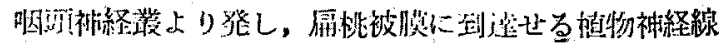

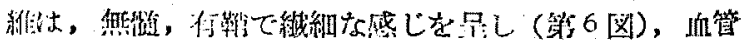

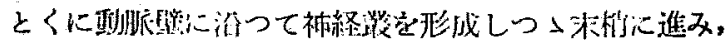

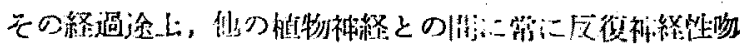

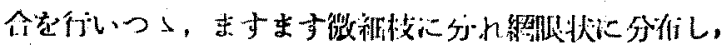


知覚神経線維の如く自由袖経終末を形成することはな W.

扁桃被膜にみられら植物神経住，数多くの神経束を形 成する加（第 3，5図），一部つ神経線維は鞘を失い，原 線維のみとなつて豊富な血管網に沿つて走行し，血管周

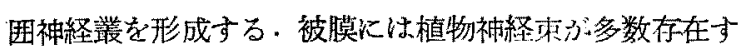
るのに反し，利覚神経束は少い。

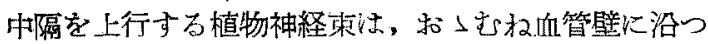

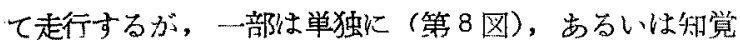
神経線䊒ととるに末佾化進み（第9図），上皮直下の固 有啳に達し，主として血管周囲に網眼状の植物神経終網 を形成する（第 14 図）.

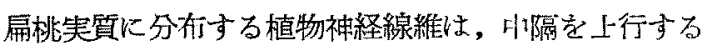

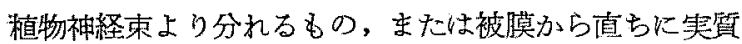
に入るものがあるれ゙，これらの神経線維生実質に入る前 にすでに無鞘となり原線維のみとなる。

リンパ小節に分布する植物神経線維は，リンパ小節の

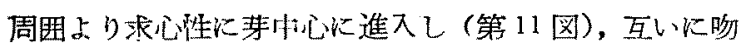
合しつ小中心谁むに従つてますます微細枝に分れ，網 眼状の植物神経終繢を形成する（第12図）。この終網は

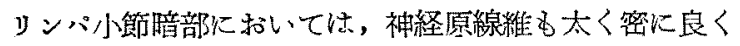
梁出されるが，明部すなわち芽中心に括いては非常に蟣 細でむしろ轫な感じを呈する かように植物神経線維 は, 全体として一つの閉鎖されたリンパ小斯に一致した 終絧球を形成しているが，しかしながら組織学的に，六 感, 副交感両神経線䧽の判別は明らか心し得ない。

扇桃火分布する植物神経束内には，いわゆる植物神経 細胞(形態学的には交感神経細胞とほぶ同一構造を示す) は全く諗められなかつた（第17，18図）。

\section{第 IV 章 病理組織学的考按}

A. 屚桃上皮の角化招よび扁桃被膜における 筇線維，粘液腺の分有について

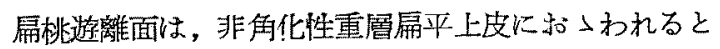
記載 18) されているが，私が検索した症例はすべて上皮 の肥厚を示し，さらにこれが角化を示している。これは

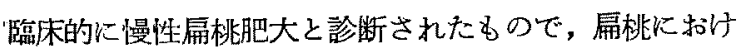
る慢性炎症の刺㦸のために佂化をさたしたるのと思われ

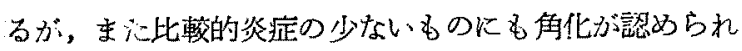
ることより，正常とみられる屚桃に手化が存在するる のと推察される ${ }^{19}$. この点に関しては，今後の砛究をむ そなければならない。

扇桃被膜は粘膜梁部の結合織心由来し，多数の弾打線

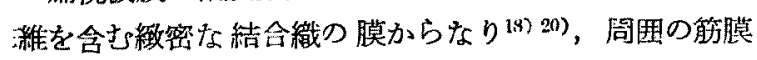

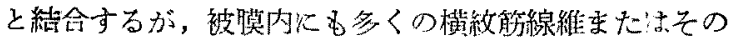

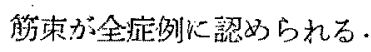

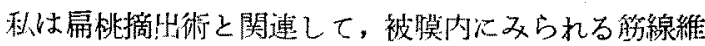
壮よび粘液腺の分括状態を症例 20 につい検索し，第 I，II表》如き成績を得た。これらの解線維扣上び触束 の走行は，一般に不規則な配列を示し，ちるものは実質 に接近して走行し、またむるものは吅焉にまで進入して

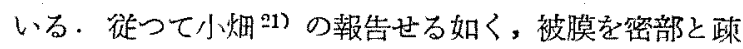
部にわかつことは，必らずしも妥当でない上5炕思われ

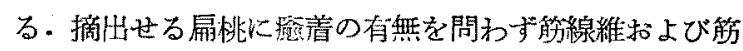
束が諗められ，さらに結合織の肥厚をきたすところの情 畕の有艠性，必らずしも被膜の厚さに平行するものでな いことは，個体の本留的差異を推定せしめる、すなわ ち，扇桃肥大にも程大の大きさが存在子る如く，被膜の 性状を種々雑多で告る。

筋組織と同しく，粘液腺の発逵拉よびその存在場所も 非常な個人差を伴うるのであるが，がいして舌口蓋弓側 には粘液腺の発達が著明である。

加よ 5 に紴膜は，便宜上臨床的に命名されたもので， 組織学的には粘膜固有屠に所属し，決して被膜としてと くに拘束されるべきむのではない。

B. 知覚神経の分布比ついて

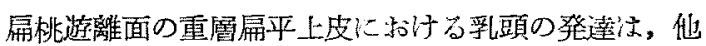

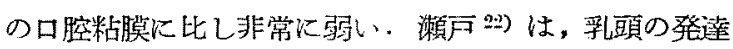

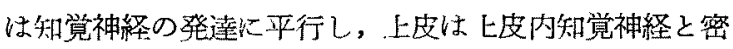
挼な関倸を示すと述べている。私が扇桃上皮ならびに上

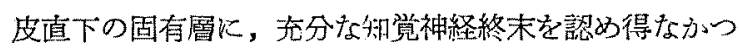
たのは，明らかにこれを支持するもので学る。な枕，扇

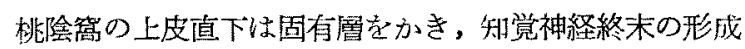
は殆んど存在しなからた。

朋桃上皮直下の固有層心みられる終末様式は, 主とし

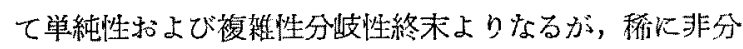
岥性終末，単純性㐘球状終末存在寸る。しかしなぶ

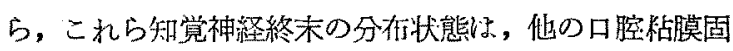

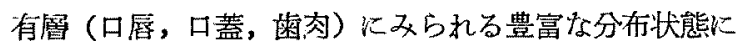

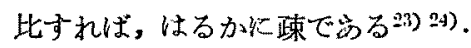

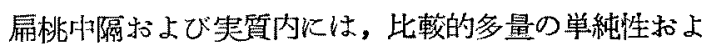

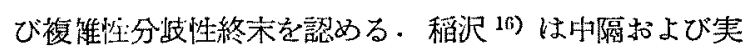
質内にも比較的単純な糸㲑形成の存在を報告している が，私は上皮值下にみられるが如き興型的な㐘球状終末 は認めなかつた。

扁桃被膜に分布子る利賞神経終末に成しては，末た詳 細な報告をみないが，被膜内には扁桃上皮值下の固有屡 
にみられてよりる，さらに多量の塑純性执上び複雑性分

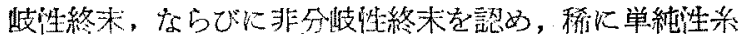

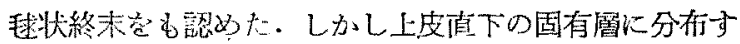
る終末样式と比較ずれば，被膜内では算純性分肢性終末

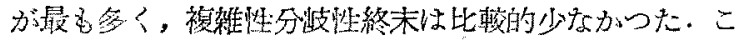

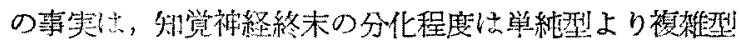

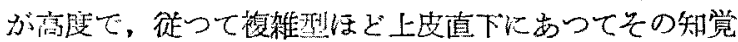

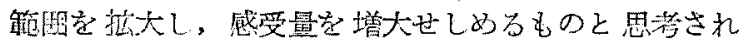
る.

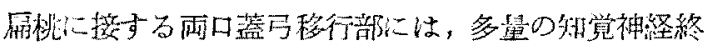

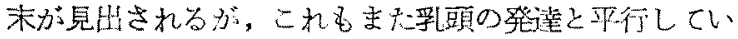
るよう化思わ机る。

和覚神経終末部儿しぱしば認められる特殊細胞につい ては，末だその機能は明確にされていないが，瀨戸22) はこの細胞は Schwann 氏細胞の 分化によるものと考

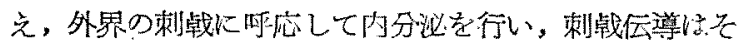
の分泌物が神経終末要素を二次的に刺战することによつ て行われるぬのと説明している。

3. 植物神経の分柯について

徉来植物神経の終末様式位，知覚神経と同様に遊離泩 終末として認められ，刺㦸伝尊も Langley の/1ロン 説で説明されてきたが，Stöhr 特上び Reiser の研究 により植物神経終網として分布することが明らかとな り, この事䒠( - Riegele ${ }^{28}$ • Kr ümmel • John - Daubenspeck • 瀨 戸22）などにより各㖑器において証明された。私は雇桃 に赫いて，微細を植物神経終絧を染出することに成功し た.とくにリンバ小節の周困から, 植物神経線維が、求心 性仗前毛細管と同行して進入し，放射線状にリンパ小節

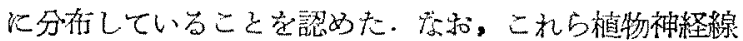
維は，毛細管㓮柬に終絧を形成しているものと思われ る。

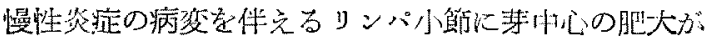

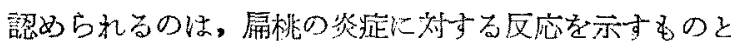
思われ，この反応は微細な植物神経終網があず外来刺镜 に反店し，ついでリンパ球の座生を促進させるためで志 万弓。

扁桃には植物神経線維の纷存が非常に豊富であるが， これは扁桃汸外来刺㦸の受容器官として口峽红位し，全 身の植物神経と密関連し，生体の反応火重要な役割员 演じているるのと思われる99)。

植物神経において, 交感, 副烄感両神経線維の組織学: 的判別は現在のところ不可能である。これは微細な植物
神経終綣が，交感，副交感両神経要素によつて形成さ れ，外来刺战に対する反応はこの共有終網により行わ

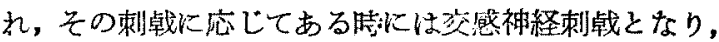
またある佶沈は副交感神経刺钱となるものと思考される からで吉る2939)。

\section{第 $\mathbf{V}$ 章 臨床的考察}

私は上上の病理組織学的結果より，次の如堂臨床的考 察を加光た、るち万ん，こ机には種なの暑論が加えられ ることつ思らがこれを機会炕さらに究明が行われるな らば,私の究いとするところである。

1. 屚桃摘出術の際漫潤麻酰にさきだつて，扁桃上皮 ならびに上皮直下゙の固有層にみられる疼痛を臨床的に検 查してみると，疼痛の訴兄は口蓋粘膜に比し少いことか゚ わかる。これは扁桃上皮ならびに上皮直下の固有圈にお

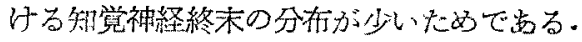

しふるに 扁桃被膜は粘膜固有圈の一部之考えられる が，私、は被膜内，とくに雨口蓋弓移行部に比較的多量の 知覚神経終末を観察した。従つて疼痛感が強いから，扇 桃摘出術の際には，充分は浸潤麻醋吕被獏内に与えられ なければならない。

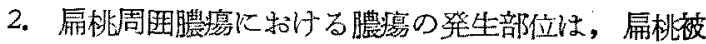
膜の外部队むつて被膜と上咽頭収縮筋との間陣に貯膿し たものと考えられているが，䇤木 ${ }^{31)}$ は従来扁桃周囲膿

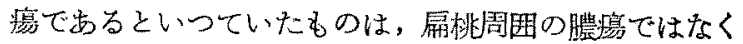

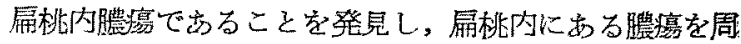
因膿㿑と呼ふことと間遠いであることを指摘し，屚桃膿 癔々改称すべで台ると提唱した。

私は扁桃陸窩の構造，個人差の多い被膜の性状（第IV 章第 1 項参照), 細菌感染力拉よび 個体の抵抗力など諾 条件觉考慮し，次の如き考察を加えた。すなわち，涮桃

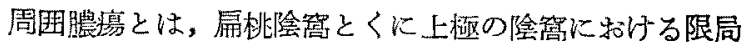

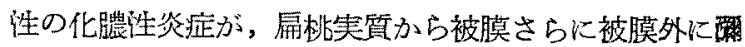
漫性に波及したもので，いわゆる䗋语織炎に相当しここ れが限局化して膿汁の蓄積したものぶ，扁桃周国膿瘍で

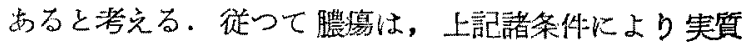
内，被膜内亲たは被膜外形成されるるのと思われる。

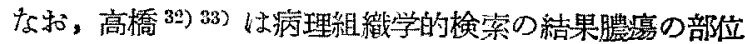
型に大別し，そのいづれの型に㨟いても共通とする ところは，澧演の一部に周囲澧瘍の発生源としての扁桃。 組織が壊囬化して消失し，しか子膿煬腔が主に肥厚，浸 淈した被膜間に進展抬大していることを認めている。

扁桃周囲膿媓の自覚症状として，本症の急性期にみら れる疼痛生非常にはげしいが，これは扁桃被膜に存在す 
る比較的多量の知覚神経終末が炎症の直接刺㦸をうける こと，括よび扁桃実質，吅隔，上皮下固有圓さらに口 蓋, 咽頭粘膜の緊張による疼痛で专ろう。

最近本症の患者に，しばしば心電図上心笳障碍の存在 することが这目され，扁桃摘出術によつて治痃せる紫等 は, Reilly 現象 34)-3s) に上る説明の妥当性を感ずる。

なお，扁桃周团膿瘍とReilly 琴象に関しては，当教

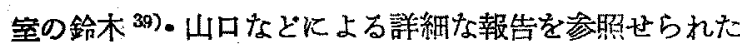
W.

3. 彷来病栄感染 (focal infection) の機權について は，全く細菌学的な見解が重要視されていたが 40)、私 はこれに Reilly 現像の立場から考察を加えてみた。

J. Reilly ${ }^{41)}$ は，内葴神経や腹腔神経節むるい:腎 動脈周囲植物神経叢にこくく微量の物質（例宇ば細菌，細 菌毒素, 化学物質なぞ) 学附意せしめて，蛋白尿，血 尿，時沉無尿をきたすことを実験的に証明した。彼はさ ら沉，府桃周囲乱よび口盖粘膜にも上記刺战物質をこくく 微量注入し，同樣の腎性変化とともに血中残余空索の上 昇を認め，あたかる人間の急性系球体腎炎汇括けると同 様つ病像を動物につくることに成功した.

私は扁桃に豊富な植物神経終網の存在することを明ら かになし得たが，慢性炎症の際にも終絧が炎症による式

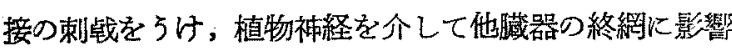

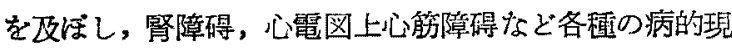

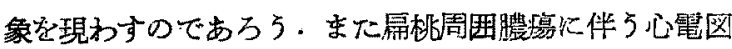
上心筋障碍もこれと同じ Reilly 現象として考察され る.すなわち、これら諸臓器の障碍は植物神経系の生体 に刘する警告を意味するものであるう，従つて警告と逆 飞生体住対す適応る当然思考されねばならない。これ を実証するものに，吉利 42)の大小胃における垁験成綪 がある.彼は車側迷走袖経を甽断してる胃壁内神経要素 にはなんら退行变性を認めず，切断により胃液分必は一 時減少を示すが，これる間すなく正常に恢復すると報告 している・また Sunder-Plassmann は甲状腺㶩执いて 同㴍の実験を報告した。

これら二つの異つた現䍇，すなわら，警告および適心

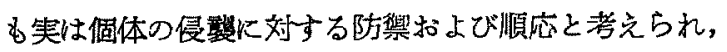
これらは植物神経系の終網によつて行われるすのと思わ れる.扁桃摘出術の際汇，時として若起されるノボカ1 ン・ショックも，外来刺㦸に対する植物神経の過敏なら びに異常感受性に起因するすのとすれば説明ずららる であろう.ショック死の剖検例にみられる諸藏器の病变 む，全身植物神経の反応を加味しているるのと思考好ら
れる43).

かように植物神経系沉特いては，未梢と中枢とつ密接 な関係のるとに, 交感, 副交感両神経線維生絶えず一体 となつて植物神経終網を形成し，内分泌系の密接な協調 と相侯つて，外染剩战江刘する全身の調和和よび内部環 境の恒常性を保持するための偉大な有機的機能の役割を 演でていること方理解できよう。

\section{第 VI 章 結 論}

私は、慢性扇桃肥大と䛦断された外来患者 10 名の摘出 屚桃を使用し，パラフイン包理叔よび凍結切片を作成 し, 扇桃の病理組䋥像执よび神経分有々くに植物神経の 分布状態索統的に追求した。

扇桃遊離面の重層屚平上皮には，全症例侮化が認め られ，まて哌桃被膜の組織学的構造には個人差が多く， とくに横紋筋線維拉よび筋束の走行は種き雓多であり， しばしば実質と接近して走行し、また中隔入口部に進入 しているのを諗めだ，従つて被膜は，組織学的には粘膜 固有層に所属し，決して被膜としてとくに拘束されるべ きものではない。

この所見を主なる根拠とし，さらに細菌感染力，個体

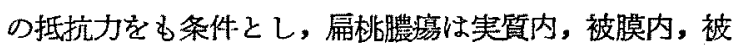
膜外いつれれを形成されうるものであるとし，扁桃周囲 膿痘の本態汇ついて言及した。

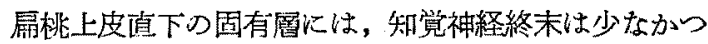
たが，瘄桃被膜とくに雨口蓋弓移行部沉比較的多量の 単純性扣上び復就性分忮性終末を認め，また非分忮性終 末, 稀に単純性米球状終末をも認めた。な特, 扁桃実質

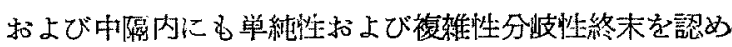
たが，上皮内神経は全く存者しなからた。

植物神経は，榃桃の位置的関係の重要性を意味するた めか，非常に豊富汇䜑められ，血管壁々所々に神経性吻

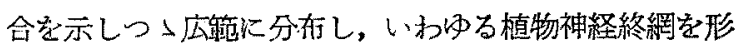
成する・とくに神経原線維が，リンパ小節の周囲から求 心性汇莱中心進入し，放射線状にリンパ小節に分布す る前毛細管と同行するのを認めた。

以上の所完を根拠として，扁桃周囲㤟㾇特の激烈な疼 痛を説明し，扁桃手術に際しては，主として扇桃周国被 膜とくに両口盖弓移行部に麻酔液を注射することが合理

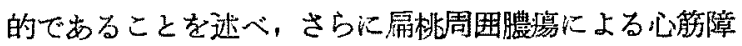
碍の如き扁桃の病巣感染を Reilly 現象の立場から考察 した・すなわち，扁桃汇ある豊富な植物神経終網による 生体に対する警告と順応であるとし，教室の臨床例や文 解にも言及した。 


\section{主 要 文 献}

1) V. Jabonero et al.: Acta neuroveget. Supplement., 4:3, 9, 117, 131, 1953.

2) G. Börger: Acta neuroveget., $13: 485,1956$. Acta neuroveget., 14:16, 1956. 3) V. Jabonero: 4) E. van Campenhout: ibid., 14: 34, 1956.

5) H. Hermann: ibid., 14:67, 1956. 6) A. Bullon Ramirez: ibid.,

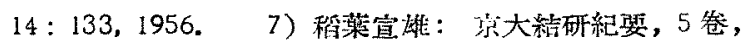
$2 \frac{1}{5}, 237$, 骂32年. $\quad$ 8) P. Martin: Peripheral vascular disorders, E. \& S. Livingstone Lid. Edinburgh and London, 1956. 9) P. Stöhr jr.: Lehrbuch der Histologie, 215, 225, 1951 . 10) 做

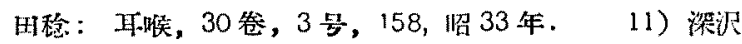

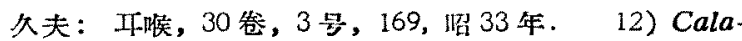
mida: Giorn. roy. accad. med. Torino, 62: 525, 1899，16）引用. 13）山崎城之眇他：東北医誌，38

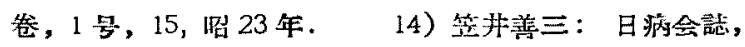
24 管, 330, 炤9年. 15) 岡本重焳：工喉, 10 资, 8 号, 763, 炤 12 年. 16) 稻沢嘉夫：東北医誌，42 替, 43，沼 24 年. 17) B.M. Mlechin: Vestnik

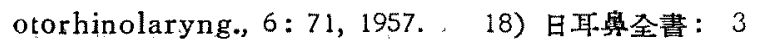
卷, 2 册, 16,123 , 炤 28 年.

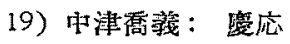
医学, 35 卷, 1 号, 31 , 沿 33 年. 20) 山川勥四阤:

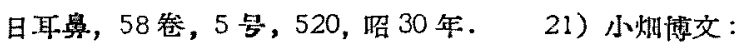
福閐医誌, 42 卷, 12 号, 1096, 昭 26 年。 22) 瀨下 八郎：人の知㞺，医学書院，炤 32 年.

23) 酒井湭

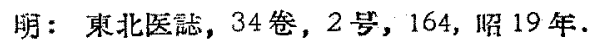
24) 传: 藤誠：東北医誌，46忩，6装，517，昭27年。 25) J. Boeke: Anat. Anz., 86: 150, 1938. 26) $P$ Sunder-Plassmann: Dtsch. Z. Chir., 252: 1, 1939. 27) P. Sunder-Plassmann, W.H. Richter: Klin. Wschr., $22: 484,1943$. 28) L. Riegele: Z. HalsNasen- u. Ohrenhk., 33: 239, 1933. 29) 菊地三

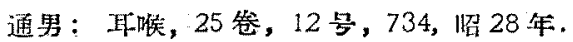

30) 占

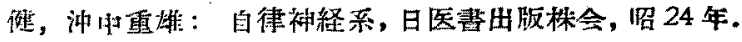

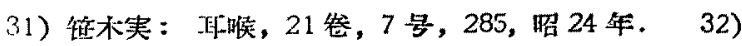

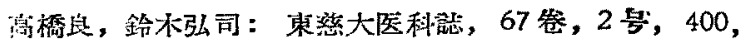
沼 27 年. 33) 山本常市: 耳续, 25 卷, 12 号, 707, 沼 28 年. 34) P. Chauchard: L'Equilibre sympathique. (植物神経と生体反店, 山口与市, 鉿木安恒,

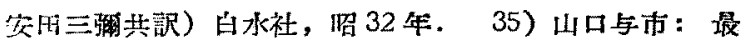
䉼医学, 10 卷, 2 号, 158, 10 量, 240, 昭 30 年. 36) 軨本安恒：日任医学，3卷，4是，11, 昭 32 年. 37) H. Laborit: Réaction organique à l'Agression et Choc. 1955, (侵軗に対寸万生体反応とショック，山口 年甫他訳) 堤新医学社. 38 ) $H$. Selye: The story

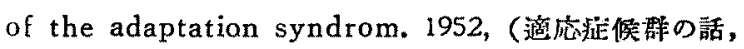

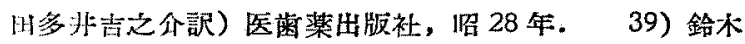

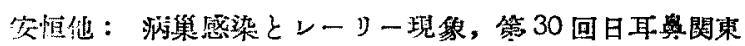

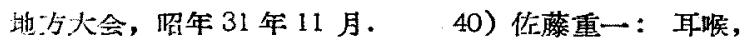
25 管，12국，712，弨 28 年. 41）J. Reilly: Comp. Rend. Soc. Biol., Paris, 148: 15 16, 1374, 1954.

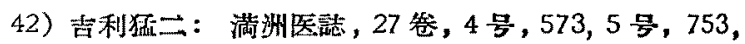

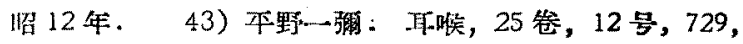
炤 28 年,

稿を終るに゙かたり，钔指薄，䃑校閴を賜つた

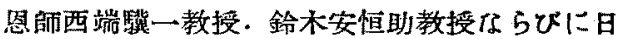

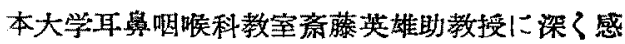

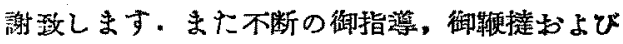

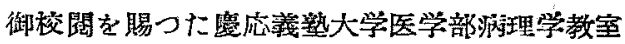

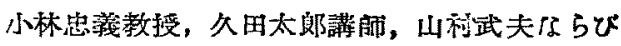
に寺島文婎両生生に深甚谢意を表します。

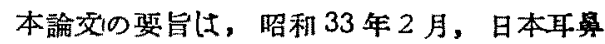
䏹缷科関果地方会第352 回例会に゙おいて報告し t.

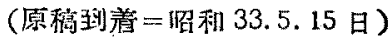


永瀬論文附図।

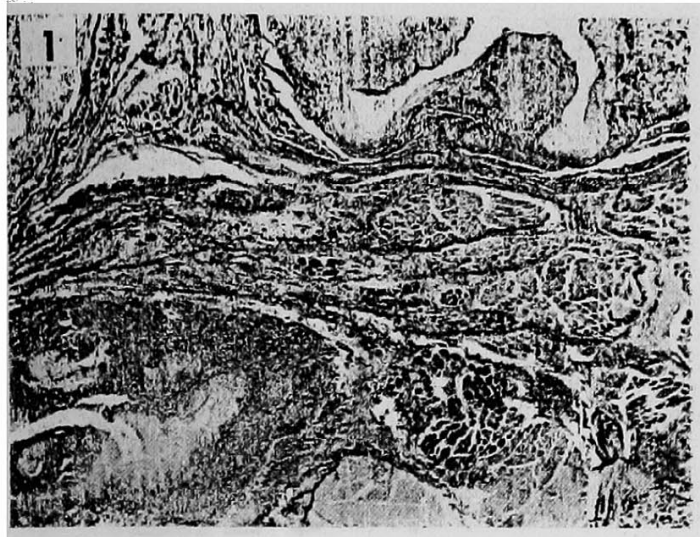

第 1 図届桃山隔に進入している不覞則ふ

㭴紋伤線維とその微束. Ḧ̈matoxylin-

Eosin 染色 $\times 30$

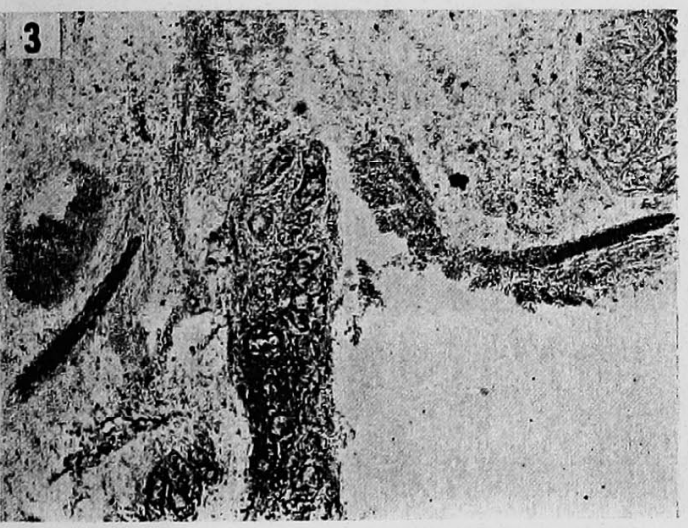

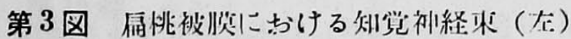

と被物神経束 (右). G-S (Gros-Schulze

の咯) 法 $\times 100$

5

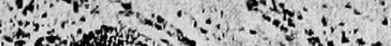

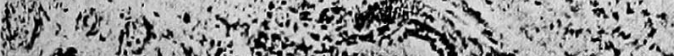

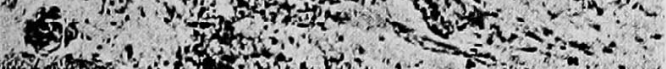
(3)

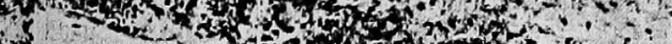

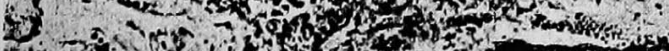

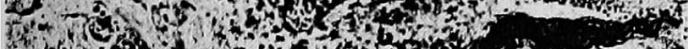

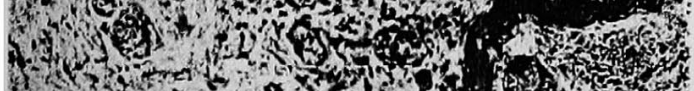

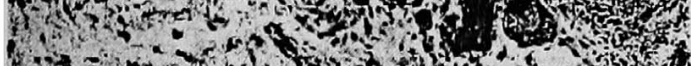

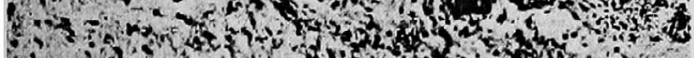

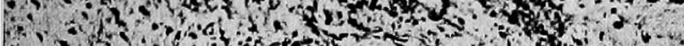

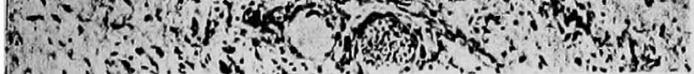

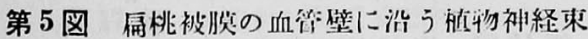

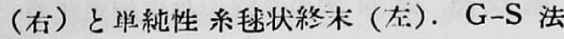
$\times 200$

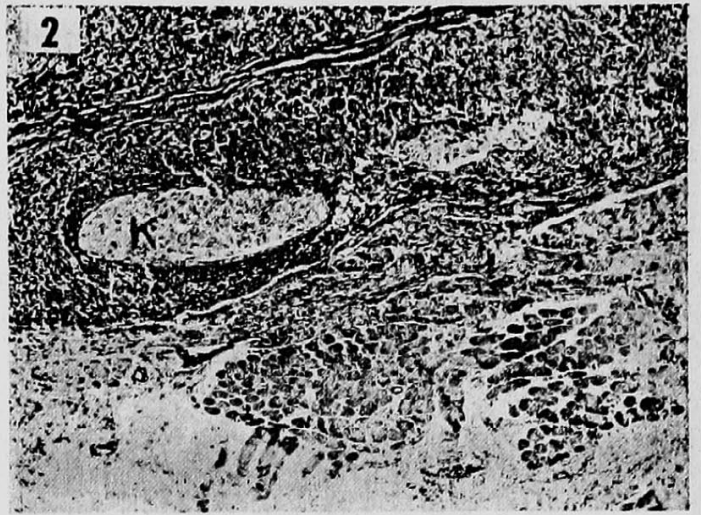

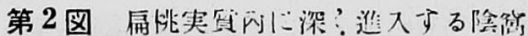

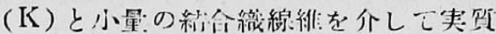

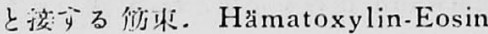
染色 $\times 80$

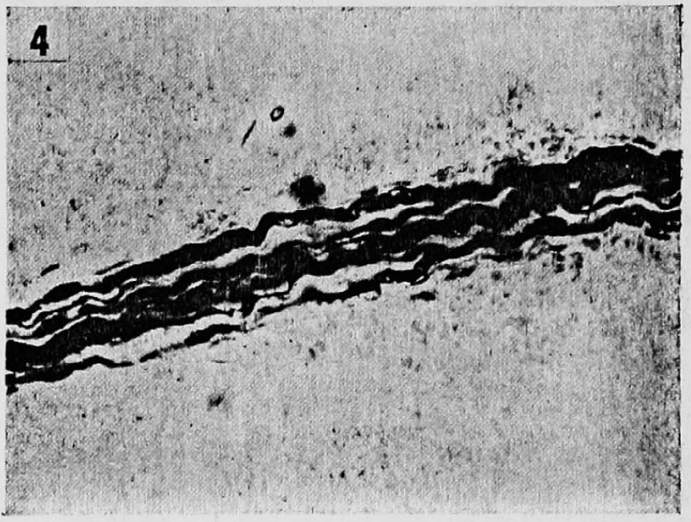

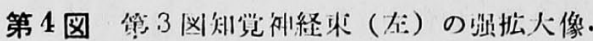
G-S 法 $\times 500$

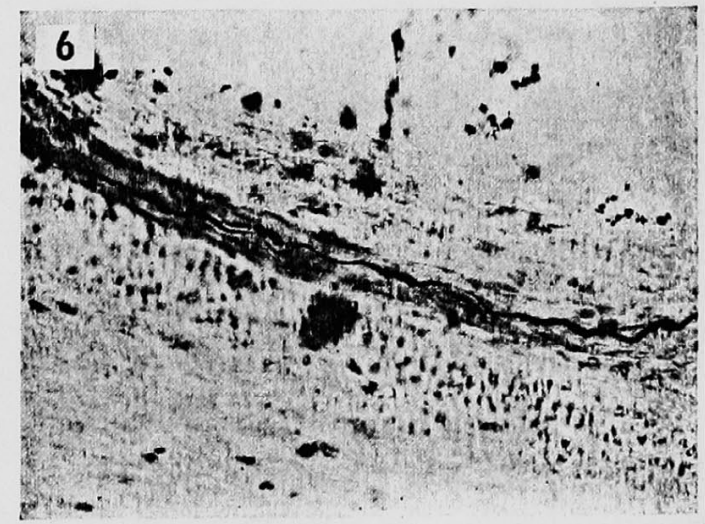

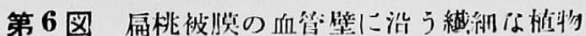
神経線維で Schwann 氏核を認も、G-S 法 $\times 600$ 


\section{永㖽論文附図 I}

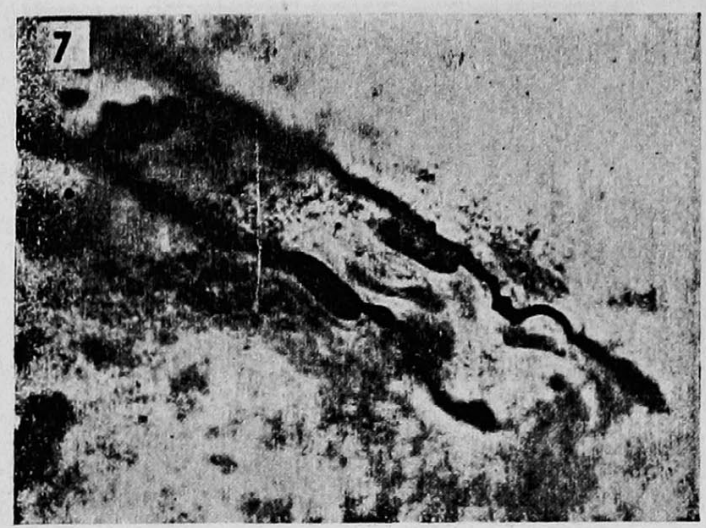

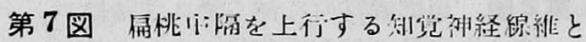

Schwann 代核を示す.G-S 法 $\times 800$

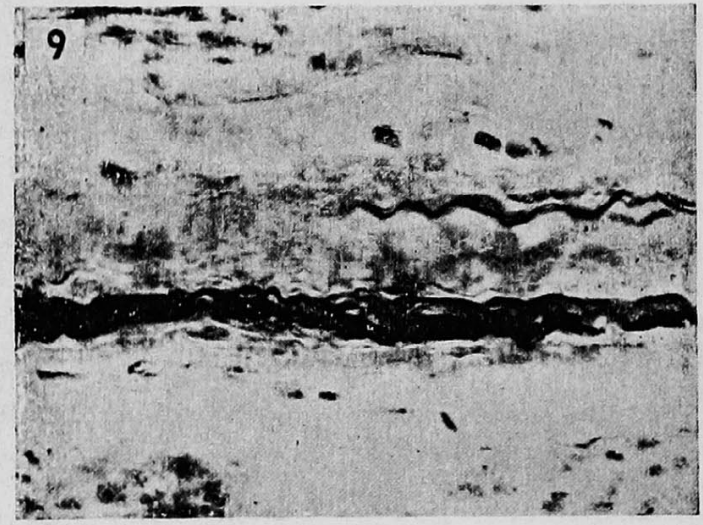

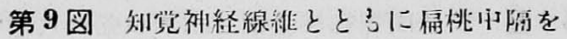

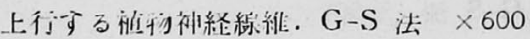

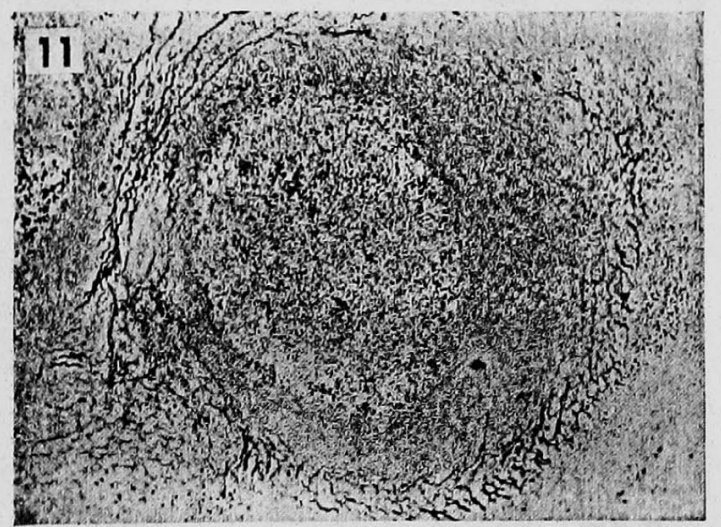

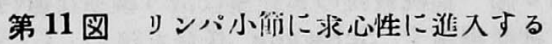

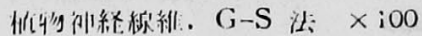

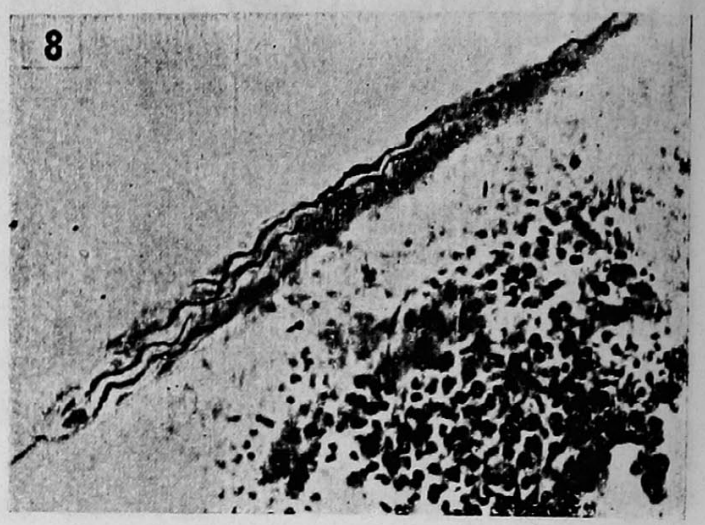

第8图槅桃り所を上行する㮌沟神経束.

G-S 法 $\times 500$

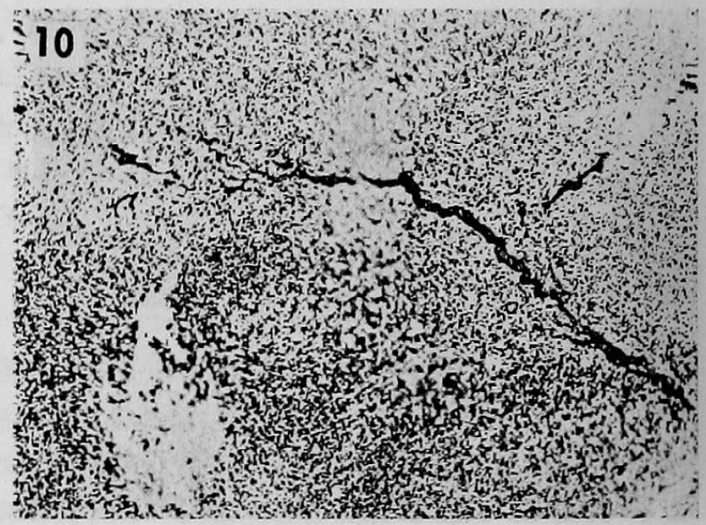

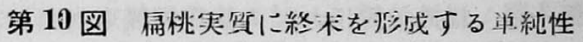

分览性終术， G-S 法 $\times 200$

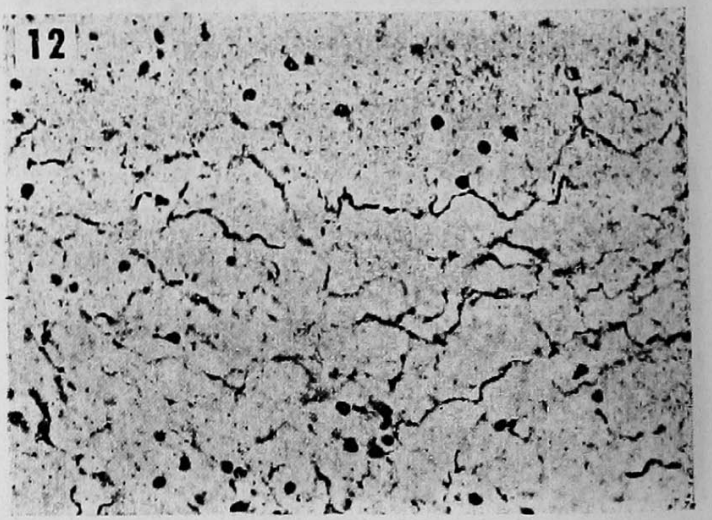

第 12 図策 11 这の促拡大像で緗腿状の

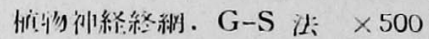



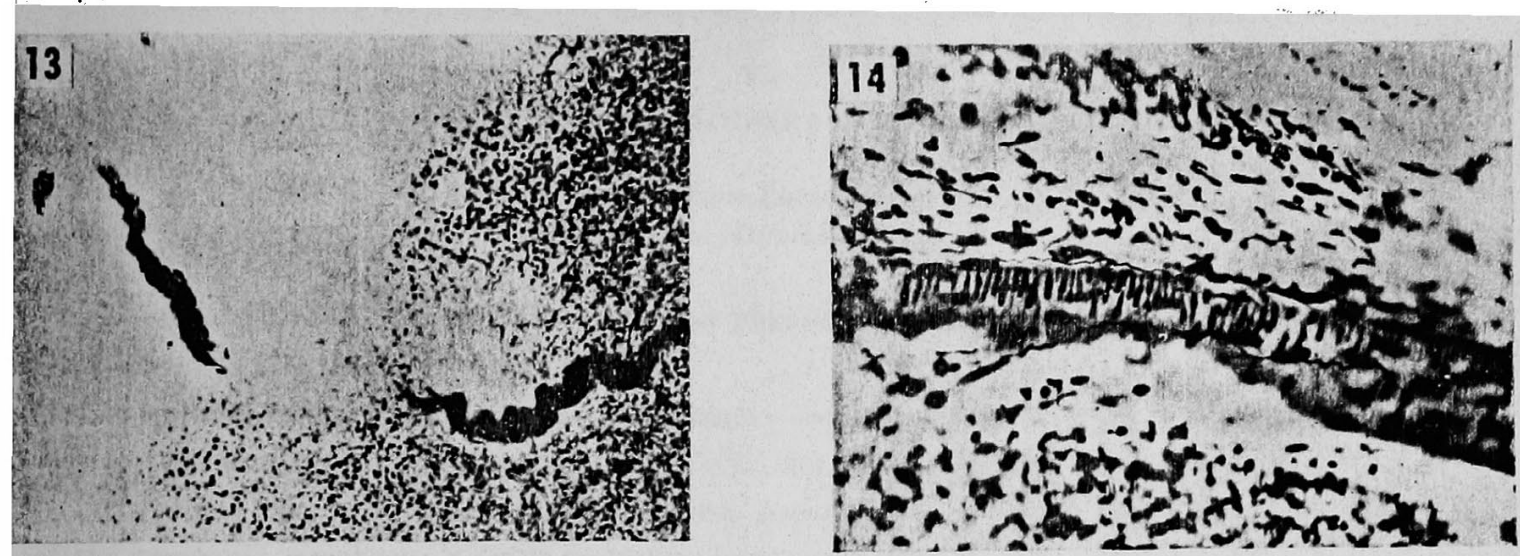

第 13 图届桃先照を比通し，上文下

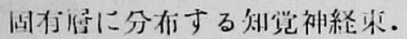

$\mathrm{G}-\mathrm{S}$ 法 $\times 200$

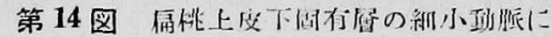

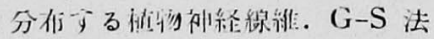

$\times 500$
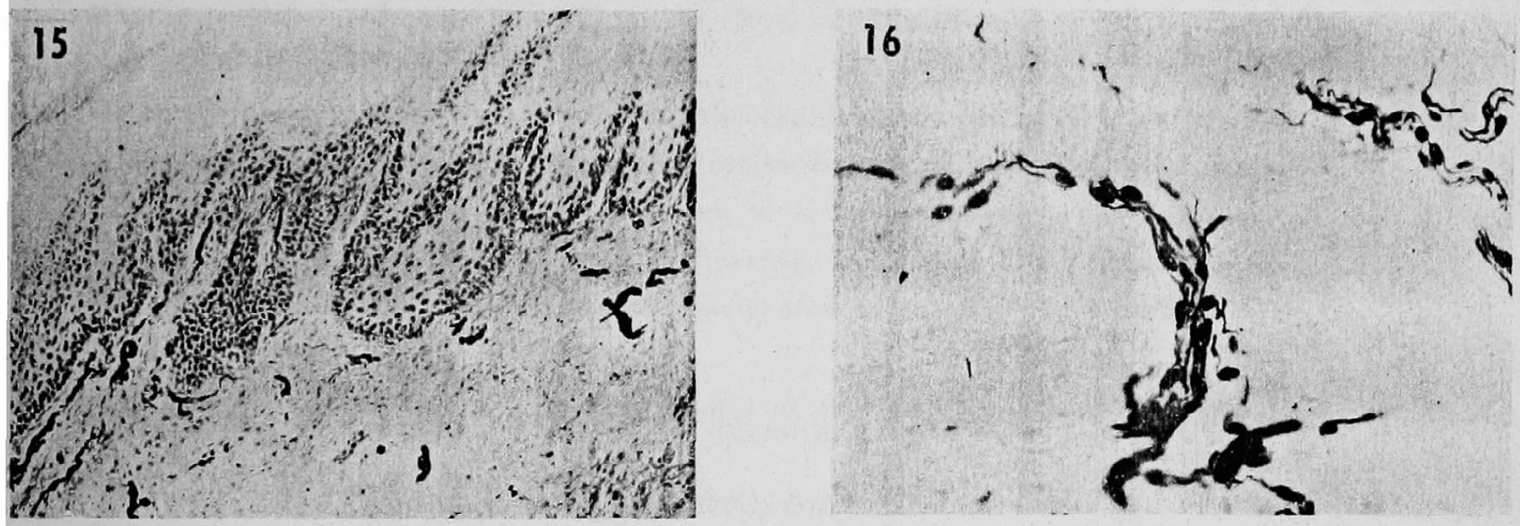

第15図モルモットの口藍には知觉神経か

多く、これは乳洏の発沽に平行する。

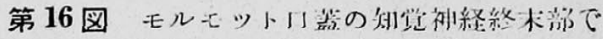

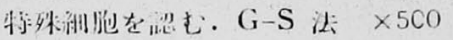

$\mathrm{G}-\mathrm{S}$ 法 $\times 100$

\$17 की (n)

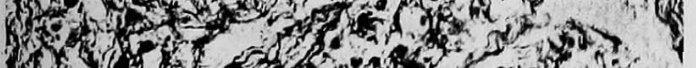

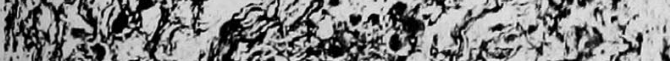

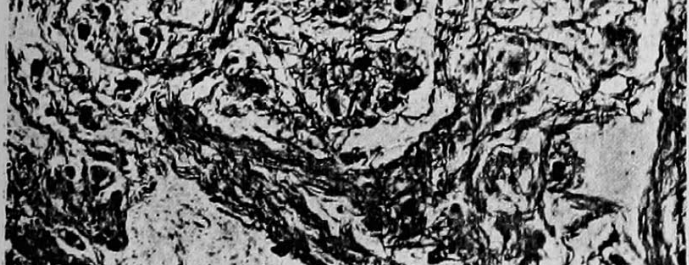

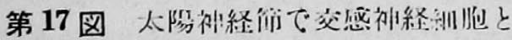

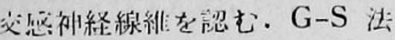

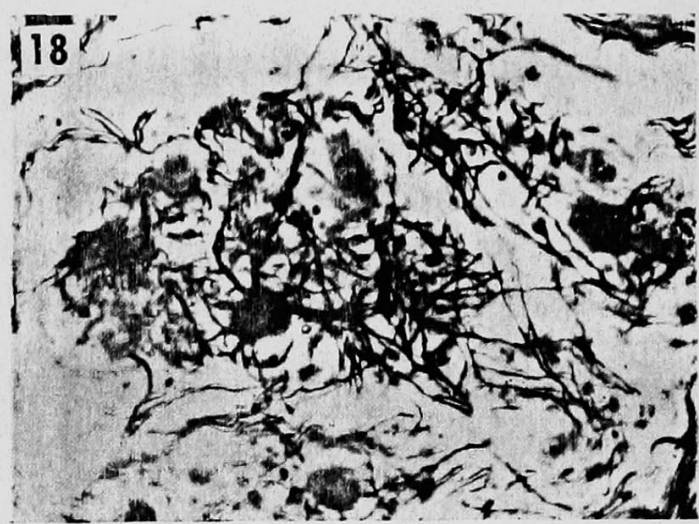

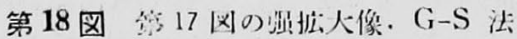
600 